\title{
PENGARUH PERSEPSI SISWA TENTANG KETERAMPILAN MENJELASKAN GURU TERHADAP PEMAHAMAN MATERI AKUNTANSI (Studi Kasus di SMAN 1 Pakusari Semester Genap Tahun Ajaran 2016/2017)
}

\author{
Tri Suci Ulamatullah ${ }^{1}$, Retna Ngesti Sedyati ${ }^{1}$, Bambang Suyadi ${ }^{1}$ \\ ${ }^{1}$ Program Studi Pendidikan Ekonomi, Fakultas Keguruan dan Ilmu Pendidikan, Universitas Jember
}

\begin{abstract}
The purpose of this research is to know the significant influence of students' perception about explaining skill of the teachers which consists of 6 indicators those are clear, structured, using example, emphasis, interesting and reversal to the understanding of accounting material in SMAN 1 Pakusari. Determining method of research location used Purposive area in SMAN 1 Pakusari, Jember. Determination of respondents in this study used population method and there were 61 students. Data collection method used consists of some methods: questionnaires, interviews, observations and documents. Data analysis used is inferential analysis that is by simple regression line analysis, regression line variance analysis, F test and effectiveness of regression line / coefficient of determination. The results showed that students' perception on the teachers' explaining skill has a significant effect on the understanding of accounting material that is equal to $79.3 \%$, is mean the perception of students on explaining skill given a positive impact to the understanding of accounting material while the remaining $20.7 \%$ is influenced by other independent variables that are not examined in this study such as the use of learning media, motivation and students learning interest.
\end{abstract}

Keywords: The perception of students on explaining skill, Comprehension of accounting material

\section{PENDAHULUAN}

Pendidikan merupakan hal yang penting dalam meningkatkan kualitas sumber daya manusia karena dengan sumber daya manusia yang berkualitas akan mampu mengolah sumber daya alam yang melimpah untuk dapat memenuhi kebutuhan manusia. Lulusan yang berkualitas juga bergantung pada kualitas pengajar yang profesional di dalam penyampaian materi yang diberikan pada saat kegiatan pembelajaran disekolah. Pembelajaran yang baik sebenarnya adalah proses belajar mengajar yang terjadi interaksi yang baik antara siswa dan guru, materi yang disampaikan guru dapat dimengerti oleh siswanya. Sehingga agar kegiatan pembelajaran dapat efektif dan efisien maka seorang guru harus memiliki beberapa keterampilan yang harus mereka kuasai.

Keterampilan menjelaskan suatu kegiatan yang dilakukan oleh seorang guru dalam upaya untuk memberikan pemahaman maupun pengetahuan kepada siswa. Dalam pembelajaran sangat mustahil jika keterampilan ini tidak dilakukan oleh seorang guru. Penjelasan yang bersifat sederhana dan kompleks semuanya bermuara pada tujuan yang sama yaitu mendapatkan pemahaman siswa (Rasto, 2015:60). Melalui keterampilan ini maka siswa akan banyak menerima informasi, ide, maupun pengetahuan baru yang dijelaskan oleh guru. Ciri utama keterampilan penjelasan yaitu penyampaian informasi yang terencana dengan baik, disajikan dengan benar, serta urutan yang cocok (Asril, 2013:84). Hal ini dilakukan untuk menyamakan persepsi siswa dengan tujuan yang diharapkan dalam tujuan pendidikan.

SMA Negeri 1 Pakusari adalah salah satu sekolah menengah atas yang ada di kabupaten Jember yang masih menggunakan Kurikulum Tingkat Satuan Pendidikan (KTSP). Salah satu mata pelajaran yang diajarkan di SMA yaitu mata pelajaran akuntansi yang diajarkan pada kelas XI semester genap. Menurut Mohan, R (dalam Rasto, 2015:55) Keterampilan menjelaskan 
bertujuan memastikan bahwa penjelasan tersebut dipahami siswa. Agar siswa dapat memahami selanjutnya dapat mengaplikasikan penjelasan guru dalam bentuk tes belajar siswa. Beberapa komponen keterampilan menjelaskan yang dapat dikuasai guru yaitu jelas, terstruktur/sistematis, Penggunaan contoh, penekanan, menarik, balikan.

Berdasarkan hasil observasi di SMA Negeri 1 Pakusari ketika menjelaskan guru menggunakan suara yang dapat didengar seluruh siswa dan bahasa yang mudah dipahami oleh siswanya. Selain itu pada saat menjelaskan materi akuntansi disesuaikan dengan materi yang mudah ke materi yang sulit dipahami siswa dan dimulai dari materi yang sudah diketahui oleh siswa ke materi yang belum diketahui oleh siswa. Memberikan contoh pada materi akuntansi seperti menggunakan transaksi-transaksi yang biasa dilakukan siswa dalam kehidupan seharihari bertujuan agar siswa lebih mudah untuk memahami materi dan contoh yang diberikan sesuai dengan kenyataan dan berkaitan dengan kehidupan sehari- hari siswa. Ketika menjelaskan pada saat terdapat materi yang penting juga harus diberikan penekanan sehingga membantu siswa untuk dapat memahami dan mengingat materi akuntansi. Guru memberikan humor namun berkaitan dengan materi agar kondisi pembelajaran tidak membosankan sehingga siswa dapat memahami materi yang diberikan guru. Pada akhir menjelaskan guru selalu memberikan kesempatan kepada siswa untuk bertanya tentang materi yang belum dipahami oleh siswanya.

Keterampilan menjelaskan guru di dalam kelas tersebut dapat dipersepsikan oleh siswa, karena Persepsi Siswa merupakan suatu proses untuk menggabungkan dan mengorganisasi suatu data melalui alat indera mengenai hal yang ada di sekeliling mereka. Guru merupakan faktor yang mempengaruhi berhasil tidaknya proses belajar dan karenanya guru harus menguasai prinsip- prinsip belajar di samping meguasai materi yang diajarkan (O. Hamalik, 2015:33). Siswa dapat mempersepsikan cara guru dalam menjelaskan karena ketika pembelajaran berlangsung siswa dapat mempersepsikan bagaimana cara guru dalam menjelaskan apakah jelas dengan meggunakan bahasa dan suara yang mudah dipahami dan didengar oleh siswa, terstruktur, menggunakan contoh, memberikan penekanan pada materi yang penting, menarik dan memberikan balikan ataupun memberi waktu kepada siswa untuk bertaya tentang materi yang belum dipahami oleh siswa.

Persepsi siswa dapat memberikan dampak pada pemahaman siswa terhadap materi akuntansi. Pemahaman merupakan Salah satu aspek kognitif yang termasuk dalam tingkat pemahaman (C2) berdasarkan taksonomi bloom. Siswa diharapkan dapat mengembangkan aspek kognitif yang tidak hanya untuk mengetahui atau mengingat materi pelajaran tapi siswa juga harus lebih memahami materi pelajaran yang disampaikan oleh guru. Adapun beberapa cara yang digunakan untuk mengetahui tingkat pemahaman siswa yaitu dengan memberikan tes kepada siswa untuk mengetahui sejauh mana tingkat pemahaman siswa terhadap materi pelajaran yang telah diberikan oleh guru. Sesuai dengan pendapat Arikunto (2015: 131) pemahaman (comprehension) adalah dengan pemahaman, siswa diminta untuk membuktikan bahwa ia memahami hubungan yang sederhana diantara fakta- fakta atau konsep.

Berdasarkan uraian di atas, maka peneliti mengambil judul mengenai "Pengaruh Persepsi Siswa Tentang Keterampilan Menjelaskan Guru Terhadap Pemahaman Materi Akutansi (Studi Kasus di SMAN 1 Pakusari Semester Genap Tahun Ajaran 2016/2017)“ . 


\section{METODE PENELITIAN}

Jenis penelitian yang digunakan oleh peneliti adalah pendekatan yang digunakan di dalam penelitian ini adalah jenis penelitian kuantitatif. Penentuan lokasi penelitian ini mengunakan purposive area, yang ditentukan sengaja oleh peneliti. Penelitian ini dilakukan di SMA Negeri 1 Pakusari, Responden Penelitian adalah siswa kelas XI IPS. Dengan jumlah siswa satu kelas sebanyak 61 siswa dari siswa kelas XI IPS 1 dan XI IPS 2.

Metode pengumpulan data dalam penelitian ini menggunakan metode angket untuk mendapatkan data tentang persepsi siswa tentang keterampilan menjelaskan guru terhadap pemahaman materi akuntansi, metode wawancara digunakn untuk mendapatkan keterangan lebih lanjut tentang pengaruh persepsi siswa tentang keterampilan menjelaskan guru terhadap pemahaman materi akuntansi, dan metode dokumen digunakan untuk memperoleh tigkat pemahaman siswa. Sedangkan untuk metode pengolahan data menggunakan editing, skoring dan tabulasi. Analisis data yang digunakan dalam penelitian ini yaitu regresi linier sederhana dan analisis varian garis regresi. Uji F digunakan untuk mengetahui pengaruh yang signifikan variabel persepsi siswa tentang keterampilan menjelaskan guru (X) terhadap variabel Pemahaman materi akuntansi (Y). Kemudian koefisien determinasi yaitu untuk mengetahui berapa besar persentase (\%) pengaruh persepsi siswa tentang keterampilan menjelaskan guru (X) terhadap pemahaman materi akuntansi (Y).

\section{HASIL DAN PEMBAHASAN}

\section{Hasil Penelitian}

Hasil analisis varian garis regresi di ketahui koefisien determinasi $R_{\text {square }}$ sebesar 0,793, besarnya $\mathrm{R}_{\text {square }}$ tersebut sama dengan proporsi sumbangan pengaruh variabel $\mathrm{X}$ terhadap variabel Y sebesar 79,3\%. Dan variabel lain yang tidak diteliti (ei) sebesar 20,7\%. Hubungan antara variabel persepsi siswa tentang keterampilan menjelaskan guru terhadap variabel Pemahaman materi akuntansi diketahui Multiple $R$ sebesar $0,891^{\text {a }}$ dengan kategori hubungan yang sangat kuat.

\begin{tabular}{|c|c|c|c|c|}
\hline Variabel & \multicolumn{1}{|c|}{$\mathrm{F}_{\text {hitung }}$} & $\mathrm{F}_{\text {tabel }}$ & $\mathrm{A}$ & Sig. F \\
\hline $\mathrm{X}$ terhadap Y & 226,253 & 4,004 & 0,05 & 0,000 \\
\hline
\end{tabular}

Berdasarkan tabel diatas diketahui bahwa besarnya $\mathrm{F}_{\text {hitung }}=226,253>\mathrm{F}_{\text {tabel }}=4,004$ dengan tingkat signifikansi $\mathrm{F}=0,000<\alpha=0,05$. hal ini menunjukkan bahwa Persepsi siswa tentang keterampilan menjelaskan guru mempunyai pengaruh yang signifikan terhadap pemahaman materi. berdasarkan data tersebut disimpulkan bahwa Ho ditolak dan Ha diterima yaitu "ada pengaruh yang signifikan Persepsi siswa tentang keterampilan menjelaskan guru terhadap pemahaman materi akuntansi di SMA Negeri 1 Pakusari.

\section{Pembahasan}

Berdasarkan pada penelitian dan juga hasil analisis data yang telah dilakukan oleh peneliti, diketahui bahwa siswa yang memiliki persepsi positif terhadap keterampilan guru di dalam menjelaskan siswa mendapatkan skor yang baik. Sehingga hal ini sesuai dengan (Karim,2013) bahwasannya keterampilan menjelaskan sangat penting bagi guru karena 
sebagian besar percakapan guru yang mempunyai pengaruh terhadap pemahaman siswa adalah berupa penjelasan.

Berdasarkan olah data yang telah dilakukan terdapat pengaruh dari variabel persepsi siswa tentang keterampilan menjelaskan guru terhadap pemahaman materi akuntansi degan proporsi sumbangan pengaruh sebesar 79,3\% ,hal ini dapat diketahui bahwasannya persepsi siswa tentang keterampilan menjelaskan guru sangat mempengaruhi pemahaman materi akuntansi siswa. Selain itu juga terbukti dari perhitungan uji $\mathrm{F}$ yang digunakan untuk mengetahui pengaruh variabel bebas $(\mathrm{X})$ terhadap variabel terikat $(\mathrm{Y})$, dimana $\mathrm{F}_{\text {hitung }}=258,948$ $>\mathrm{F}_{\text {tabel }}=4,004$ dengan tingkat signifikansi $\mathrm{F}=0,000<\alpha=0,05$. Hal ini berarti bahwa variabel persepsi siswa tentang keterampilan menjelaskan guru mempunyai pengaruh yang signifikan terhadap pemahaman materi akuntansi sesuai dengan pendapat bahwa (Marno, 2016:95) Menjelaskan pada dasarnya adalah menuturkan secara lisan mengenai suatu bahan pelajaran yang disampaikan secara sistematis dan terencana.

Persepsi siswa tentang keterampilan menjelaskan guru terkait beberapa hal yaitu Jelas, Terstruktur/sistematis, penggunaan contoh dan ilustrasi, penekanan, menarik dan Balikan (Feedback) yang mendapatkan respon positif. Sesuai pendapat (Rasto, 2016:60) menyatakan pemahaman siswa tersebut akan diperoleh bila penjelasan yang disampaikan oleh guru memenuhi kriteria tertentu. Berdasarkan hasil observasi ketika menjelaskan suara guru dapat terdengar dan dapat dipahami seluruh siswa di dalam kelas yang berisikan sekitar 30 siswa. Hal ini juga didukung oleh hasil wawancara yang telah dilakukan kepada salah satu siswa yang mendapat nilai tes baik mengatakan bahwa:

"Setelah guru menjelaskan materi, saya dapat memahami materi akuntansi karena guru menjelaskan dengan jelas suaranya lantang dan dapat didengar semua teman-teman meskipun saya duduk dibangku paling belakang dan bahasa yang digunakan tidak rumit. (AH,16 Thn).

Dari hasil observasi yang telah dilakukan diperoleh juga hasil bahwa ketika menjelaskan guru memberikan peta konsep dari materi yang akan dibahas sebelum masuk ke dalam materi selanjutnya guru juga membahas materi yang diterangkan sebelumnya. Dari hal tersebut diketahui bahwa guru menjelaskan materi dari materi yang sudah dipahami oleh siswa ke materi yang belum dipahami oleh siswa.

Penggunaan contoh dan ilustrasi juga diterapkan guru ketika menjelaskan agar siswa mendapatkan gambaran tentang proses akuntansi yang berkaitan dengan kehidupan siswa sehari- hari. Dari hasil observasi contoh yang digunakan dalam memberikan penjelasan konkret dan dapat dipahami oleh siswanya. Hal ini dapat diperkuat oleh pendapat siswa, mengatakan bahwa:

"Bu guru memberikan contoh tentang transaksi dalam kehidupan sehari-hari kepada kami ketika kami bingung terhadap materi sehingga kami mudah untuk memahami materi yang sebelumnya kami tidak paham dengan materi itu. (AH, 16 Thn)

Aspek yang lain yang ditemukan dalam observasi yang dilakukan pada saat kegiatan pembelajaran berlangsung di dalam kelas adalah guru sering sekali memberikan penekanan pada materi yang dianggap sulit oleh guru. Penekanan yang sering digunakan oleh guru yaitu 
dengan memberikan pengulangan pada materi yang dianggap sulit dipahami oleh siswa. Dan kedua yang sering diterapkan di dalam kelas yaitu menggunakan bahasa tubuh dan juga guru sering menuliskan materi yang penting tersebut di papan tulis agar dicatat oleh siswa sehingga dapat dipahami oleh siswa.

Melalui media pembelajaran tersebut siswa akan lebih cepat memahami materi karena mereka belajar juga sambil bermain sehingga pembelajaran dapat menarik. Sesuai dengan pendapat siswa, mengatakan bahwa:

"Saya senang dengan pelajaran akuntansi karena menarik, seperti biasanya Bu guru sering memberikan lelucon pada saat kita semua sedang serius mendengarkan penjelasanya namun tetap tidak keluar dari materi yang sedang diajarkan (MS, 16 Thn)

Dari hasil wawancara tersebut sudah dapat diketahui bahwa ketika menjelaskan guru sering menggunakan kata- kata humor dan menggunakan media pembelajaran agar pembelajaran di kelas dapat menarik. Berdasarkan wawancara yang telah dilakukan Guru memberikan kesempatan kepada siswa untuk menanyakan materi yang telah dibahas dan belum dipahami oleh siswa. Sesuai hasil wawancara yang telah dilakukan, guru mengatakan bahwa;

"Saya selalu memberikan kesempatan kepada siswa untuk bertanya tentang materi yang belum dipahami. Selain itu biasanya saya juga memberikan pertanyaan kepada siswa untuk mengetahui sejauh mana siswa sudah memahami materi yang saya sampaikan (AK, 37 Thn).

Berdasarkan hasil tersebut maka diketahui bahwa balikan(Feedback) sangat penting diakukan oleh seorang guru karena digunakan untuk mengetahui sejauh mana siswa dapat memahami materi yang telah dijelaskan oleh guru sehingga tujuan pembelajaran juga dapat tercapai dengan baik dalam pembelajaran.Berdasarkan hasil dari analisis data, observasi dan wawancara yang peneliti lakukan dapat diketahui bahwa siswa SMA Negeri Pakusari kelas XI IPS. hal ini dapat dibuktikan dengan sehingga permasalahan dalam penelitian ini dapat terjawab dan tujuan dalam penelitian ini dapat tercapai. Hal ini artinya hipotesis tersebut terjawab bahwa persepsi siswa tentang keterampilan menjelaskan guru berpengaruh terhadap pemahaman materi akuntansi sebesar 79,3\%. Hal ini terbukti dari nilai analisis koefisien determinasi (Rquare) sebesar 79,3\%. Guru harus dapat menjelaskan dan memberikan pemahaman berkaitan dengan materi yang diajarkan (Rachmah, 2016). Keterampilan guru dalam menjelaskan sangat berperan penting dalam meningkatkan pemahaman siswa.

\section{KESIMPULAN DAN SARAN}

\section{Kesimpulan}

Berdasarkan hasil analisis mengenai pengaruh persepsi siswa tentang keterampilan menjelaskan guru memberikan dampak terhadap pemahaman materi akuntansi. Pemahaman materi akuntansi meningkat ketika dipengaruhi oleh persepsi siswa tentang keterampilan menjelaskan guru yang semakin baik. 


\section{Saran}

Keterampilan Menjelaskan yang dimiliki oleh guru sangat membantu dalam upaya untuk memberikan pemahaman kepada siswa lebih utamanya pada materi Akuntansi. Adapun saran yang diberikan dari penelitian ini yang juga harus dilakukan yaitu Seorang guru harus memiliki dan mampu menerapkan keterampilan menjelaskan dengan baik karena siswa akan mempersepsi keterampilan guru tersebut. Dan seharusnya keterampilan guru harus selalu ditingkatkan agar pemahaman materi siswa juga semakin meningkat, Bagi peneliti selanjutnya, penelitian ini dapat dikembangkan dengan menambah variabel lainnya yang juga berpengaruh terhadap pemahaman siswa yang tidak ikut dalam penelitian ini.

\section{DAFTAR BACAAN}

Arikunto, S. 2015. Dasar - Dasar Evaluasi Pendidikan Edisi 2. Jakarta :Bumi Aksara

Azril, Z. 2013. Micro Teaching disertai pedoman lapangan. Jakarta: PT. RajaGrafindo Persada

Hamalik,O. 2015. Psikologi Belajar dan Mengajar.Jakarta : Sinar Baru Algasindo

Karim, F. 2013. Keterampilan Menjelaskan Guru Dan PengaruhnyaTerhadap Peningkatan Hasil Belajar Siswa Di SmkGotong Royong Telaga Kabupaten Gorontalo. Skripsi Universitas Negeri Gorontalo

Marno dan Idris. 2016. Strategi dan Metode Pengajaran: Menciptakan Keterampilan Mengajar yang Efektif dan Edukatif.

Rachmah S. 2015. Microteaching Pengembangan Keterampilan Mengajar. Yogyakarta: Kaukaba Dipantara

Rasto. 2015. Pembelajaran Mikro Mengembangkan Keterampilan Mengajar Guru Profesional.Bandung : Alfabeta 